\title{
Alone on a Wide Wide Sea: Exploring Narratives of Child Migration from Britain to Australia
}

\begin{abstract}
Focusing on identity formation amongst child migrants, this paper reflects on the experiences of unaccompanied minors sent from Britain to Australia in the $20^{\text {th }}$ Century. Between 1947-1967 3170 children are understood to have been exported to Australia, making Britain the only country in the world known to have exported children during peace time. Most of these children came from British care homes to which they had been entrusted by their families or social workers. The majority of exported children were from working class backgrounds and many still had living parents, or other close family, in the UK. Children as young as four were sent to train as farm labourers and domestic staff, simultaneously relieving the burden of providing for these children from the British Government, and increasing the white population in 'underpopulated' Australia. The paper presents thematic analysis of four published sources produced for a wide readership: two published memoirs and two young adult novels. The paper seeks to reflect on the impact of forced transnational migration on the children's identity formation as new Australians.
\end{abstract}

Keywords:

child migration, narrative inheritance, identity, family, public inquiry

\section{INTRODUCTION: CHILD MIGRATION, CLASS AND RACE}

For around four centuries, ending only in the late 1960s, the British government systematically organised the emigration of British children from the UK to else-

1 Lancaster University, Lancaster, United Kingdom.

E-MAIL: n.r.vonbenzon@lancaster.ac.uk 
where in the British Empire (Bean \& Melville, 1989). The first recorded incidence of child migration appears to be a group of children being sent in 1618 to Virginia in the USA (Bean \& Melville, 1989). The process of exportation of children varied in design and intensity throughout the period 1617-1967 (Coldrey, 1996), appearing to gain particular traction following the First World War. Emigration was largely curtailed between 1939-1945. However, the post war period saw over a decade of the most aggressive peace time child exportation policy in world history. Indeed, Britain is the only country in the world known to have exported its own children outside a period of conflict. Facilitated by a vast array of agencies, including the Catholic and Anglican churches, independent charities, and wealthy philanthropists, exported children travelled from the UK to Canada, South Africa, Australia, New Zealand, and the Caribbean (Langfield, 2004).

This migration, funded at least in part by the British Government, was viewed as a win-win colonial strategy (Constantine, 2002). The children sent through most of the history of the programmes were living in State care, although not necessarily orphaned. Indeed, many of the children had at least one living parent; often this was a parent who wished to maintain contact with the child or even bring the child home at some later point (Humphreys, 2011). The fact that so many of these parents had their child effectively stolen from them, and that children were later told they were orphaned and robbed of the chance to maintain or re-establish contact with parents, is a cornerstone of the contemporary understanding of the child migrant programme as a scandal (see Humphreys, 1994). However, the fact that at the time of migration, these children were resident in state-run homes, provided the state, and specifically the agencies managing migration schemes (Grier, 2002), to access children, and to justify the programme. Exportation provided a relatively low cost solution to the problem of the duty of the state to care for children who could not be cared for in the family home (Swain, 2016). Long-term prospects for these children in the UK may also have appeared bleak, particularly for children without supportive family networks leaving state care during periods of high unemployment (Kershaw \& Sacks, 2008). Certainly, in the archives of the Victorian reformatory schools such as Birkdale Farm in Lancashire there is clear concern over the future of boys 'graduating' from school at periods where it was difficult to place them in apprenticeships or other employment; for this reason emigration, typically to Canada, was deemed a sensible option.

The second 'win' of the win-win proposition of child migration was the opportunity to increase the resident white population in the particular colony to which the children were being sent (Langfield, 2004). By the 1950s, the concern in Australia was not of any real threat to white control from the indigenous non-white 
population, but a concern over the potential of increasingly densely populated East Asian countries to try and expand into the large and significantly under-populated expanse of Australia. Of particular concern were the very large expanses of sparsely populated rural areas that had experienced internal migration leading to an increase in urban populations. A desire to halt this population movement in fact led to the South Australian Government's development of an initial youth migrant scheme in 1913 (Grant \& Sendziuk, 2010). Population increase was seen as a defence strategy, and a desire to import children from the UK became a key driver in the intensification of the flow of child migrants from the UK to Australia after 1945 (Sherington, 2003).

If we are to consider this stream of child migration from the UK to Australia using the push/pull factor lens that any good high school student is taught to apply to mass movements of people, we can understand 'class' as a push factor. That is to say that the British government was clearly motivated to remove some of the poorest members of society, those currently presenting a drain on resources, and predicted to continue to present a drain on the economy through ongoing lack of education, unemployment and potentially criminal activity (Sherington, 2003). To take a particularly sinister biopolitical approach, removing juveniles of pre-reproductive age is well understood in wildlife population control to be an effective means of significantly impacting on the size of the targeted population over time. Thus, one interpretation of the child migration strategy would be as a means of significantly reducing the overall population of the poorest in British society. By contrast, whilst these young people may have been considered amongst the lowest in British society, their skin colour gave them value in the colonial context (Uusihakala, 2015). Thus the colonial governments were willing to accept these groups of unaccompanied minors as they disembarked, and financially support them whilst they grew up in the care of foster homes or institutions within the receiving country.

What is clear from this push/pull review is that at no point did child migrants act with any agency in response to 'pushing' or 'pulling'. Programmes aimed at encouraging adult, or even older teenage migration to the colonies, required marketing to intended migrants in order to secure their participation as autonomous individuals (Kershaw \& Sacks, 2008). By contrast, much as the transportation of convicts or the Scottish highlands clearances of the eighteenth and nineteenth centuries, child migrants were removed from their homes and taken across the world, without any recourse to the children's own wishes. This paper seeks to explore the impacts of this forced migration, and the subsequent childhoods as, often institutionalised, migrants in a new country, undertaking education, training 
and child-labour, on children's identities and relationships. Given the variations in process, opportunities and experiences across the different colonial contexts, this paper will focus specifically on child migration from the UK to Australia, looking specifically at the period 1947-1967.

\section{NARRATIVES OF CHILD MIGRANTS}

This paper is based on thematic analysis of four documents. These documents comprise of two autobiographical works: Empty Cradles, written by the social worker Margaret Humphries and Forgotten Children, a memoir authored by former child migrant David Hill; and two novels: Alone on a Wide Wide Sea by British children's author Michael Morpurgo and Blood Ties, a young adult novel written by British author Rosemary Hayes. Throughout this chapter, the fiction and fact of these six sources is interwoven in a manner representative of the nonbinary distinction between truth and lies and a recognition of the subjectivity of the representation of ideas in literature, whether that literature be ostensibly fiction or non-fiction. Whilst the approach of using fiction to support discussion of reality is not widespread within social sciences, this is not new within literature studies where fiction may be used as a tool to explore real-world power relations, experiences and events (Beyer, 2010). Sufficient testimony, official documentation, and public statement exist to be assured of the processes and practices of child migration. For this reason, as a researcher and author, I am happy to present 'evidence' to support my particular approach to analysis from both intentionally factual and intentionally fictitious sources.

\section{EDUCATION, TRAINING AND CHILD-LABOUR}

Whilst the agencies managing child migration were under no obligation to convince the children themselves of the benefits of migration, the agencies were reliant on the support, or at least compliance, of social workers in the UK, and adults running children's homes (Grier, 2002; Silverstein, 2017). Moreover, these agencies required ongoing support and financing from the British Government, which some agencies sought at some points to supplement through further donations from the public. As such, given the need to convince a broad range of stakeholders on the merits of child migration, the class-based 'push' factors and the racebased 'pull' factors, were not going to be sufficient justification for the removal 
of British children to the colonies (Hill, 2017; Kershaw \& Sacks, 2008). These benefits were typically presented as reflecting the perceived differences between the landscape and the economy in the UK and Australia. David Hill writes of the way in which the country was marketed to his family² as a land of milk and honey, or to borrow from the film addressing the work of Margaret Humphreys, 'Oranges and Sunshine'. The opportunity to live a healthy and outdoor-based lifestyle, with access to plenty of fresh fruit and vegetables, was presented as a highly appealing alternative to the experiences, or at least the public perception of the experiences, of working class, urban children growing up in the UK (Constantine, 2002). This presentation of the 'rural idyll' built on a well-embedded British fantasy of the propensity of the countryside to 're-educate' and 'cure' (see for example, Stack, 1979).

Along with a healthy, outdoor lifestyle, facilitators and potential facilitators in the UK were sold a narrative of a good education in classes that were less crowded, and more conducive to learning, than their British counterparts (Hill, 2017). In addition to academic learning at school, the child migrant schemes also offered vocational training that would render children highly employable once they came of age and were ready to make their own way in the world. Typically, schemes promised that boys would be taught farming and associated agricultural trades, whilst girls would be trained to make good farmers' wives able to contribute to the running of rural households and maintenance of holdings. As such, neither the UK facilitators of the schemes or the young people themselves would have been particularly surprised that the child migrants were expected to contribute to farming activities, and more general household chores, as part of their daily life. However, the extent of the participation: the gruelling workload and the long hours, went far beyond what might have been deemed acceptable by the mores of the time. Hill (2017, p. 151) recounts the words of Smiley Bayliff, a fellow child migrant:

Any way you look at it, it was slave labour. Looking back you can hardly believe they did that. How could they work fifteen- and sixteen-year-olds that hard anyway? How did they get away with it? Some of the jobs were sixteen hours a day, seven days a week. And for no wages...

2 David Hill was part of a group of migrants who came to Australia in 1959 with the Fairbridge Society under a later development of the child migrant scheme. The scheme was altered from the traditional approach of transporting children without their families, to reverse dwindling demand. In this iteration of the scheme, single parent families were encouraged to send children to institutions in Australia, under the promise that parents would then be funded to join their children later. As such, the scheme needed marketing to families, as the children participating still lived at home and under the care of their parents. 
In Australia, unlike other British colonial recipients of child migrants, a significant proportion of the arriving children were placed in institutions run by agencies such as the Fairbridge Society or the Christian Brothers. This practice highlights the power of the voluntary organisations involved in the child migration process, given that institutionalisation of children was counter to the Immigration (Guardianship of Children) Act of 1946 that applied to British child migrants to Australia. The Act reflected social opinion of the importance of raising children within a family home (Silverstein, 2017), and it appears much to the detriment of many children that this priority was not reified. These institutions, it transpired, took to using child migrants as free labour to farm and build, often engaging in back-breaking work for very long hours, often doing dangerous activities and with insufficient food or unsuitable places to sleep. Indeed, at Bindoon, a facility run by the Christian Brothers, young boys built the institution itself, moving and laying heavy stone at the instruction of the religious staff (Humphreys, 2011). Children who were fostered out and living in private homes were not necessarily leading an easier life. Arthur, the central character in Michael Morpurgo's Alone on a Wide Wide Sea, finds himself sent to a rural farm with a group of other boys. Forced to sleep in a shed, the boys undertake long hours of gruelling labour at the mercy of a demonic foster father, and are not given an opportunity to attend school.

David Hill similarly reflects on the lack of educational opportunities offered to children at the institution run by the Fairbridge Society in Molong. Here, most children were educated at the nearest school, which had a poor reputation and poor facilities. Only a very few of the brightest children were sent to a far better school in a nearby town. However, without support for their studies or time and facilities to do homework, and experiencing extreme emotional trauma, most children did very poorly in school, even where they had been doing very well in the UK. Bob Stephens, is quoted by Hill (2017, p. 204): "I see the school results and you see I'm up in one or two of the top academically, and then after two years, it deteriorates to where I'm at the bottom of the class and I think that's a reflection of my not being able to cope with Fairbridge and the whole situation of Fairbridge”. Even where children were succeeding in the Australian school system, the vast majority of children were required to leave school at fifteen, prior to sitting for their high school certificate, in order to work full time on the farm, effectively as indentured labourers, being unable to leave until they were 18 (Hill, 2017).

Child labour clearly played a considerable role in off-setting the costs of the keep of the resident children. What appears unclear is whether this activity was deemed necessary as a means of bridging the gap between what was received by the agency to cover the costs, and the actual costs, or whether this income, either 
direct through farm sales, or indirect as savings, was channelled elsewhere, supporting agency work or lining the pockets of individuals. The training aspect to this child labour is not evident in the reflections of child migrants, with little apparent adult supervision or technical training being involved in the sort of manual labour that the children were required to undertake (Hill, 2017; Humphreys, 2011). The working life of the children is encapsulated in the following extract of a poem, Song of the Child Migrants, written by Len Cowne, a former child migrant, and printed in David Hill's memoir (2017, p. iii):

Then appeared the rosters

Apportioning the work

To scrub and clean and polish

No chance to ever shirk

To till the market garden

With shovel and with hoe

Planting lots of cabbages

And taters in their rows

Harnessing the draught horse

To the single furrow plough

Holding fast the jerking handles

To plough a straight furrow

Sitting on the bucking tractor

Sowing in the wheat

Smothered in both sweat and dust

From the never-ending heat

Training for the future

The farming life ahead

But surely little migrant lad

You should be in your bed.

In terms of future employment, rural job opportunities, and particularly opportunities for children deemed 'outsiders', appears to have been sparse. David Hill talks of young people moving to cities on their release from Pinjarra, but finding employment opportunities scarce due to lack of education and relevant training. In Michael Morpurgo's novel, Arthur is sent as an apprentice to a ship builder, whilst Rosemary Hayes' lead character finds employment as a maid. The education and training that child migrants received appears to have been in many cases both insufficient and inappropriate for the sorts of jobs that were to be available to these young people upon finishing at the institution. Clearly, given that the 
institutions themselves were expected to take responsibility for supporting young people in finding initial employment, it would have been obvious to the agencies managing child migrant institutions that the practices of employment and training delivered through these institutions were not suitable to prepare young people for seeking employment. Indeed, in 1956 British Government officials were sent to inspect institutions across Australia, and flagged serious concerns about the goings-on (Humphreys, 2011). Yet institutions such as the Fairbridge Farm School continued to operate, enforcing long hours of farm labour and removing children prematurely from school, into the late 1960s.

It can be surmised that these rural institutions were relatively low cost to manage, given the offset-value of the children's labour, and that they were outof-the-way. The remoteness and associated isolation of these institutions meant that discipline was relatively straightforward as children's ability to abscond was severely limited. Therefore children would be aware that misdemeanours may be punished through the means the adults in charge saw fit, and that there would be no escape from these consequences. Thus compliance was the logical behaviour. Isolation also meant that practices that cut costs of keeping children, such as overcrowding, failure to maintain or upkeep facilities, under-staffing and poor quality food, ${ }^{3}$ were able to be administered away from interfering eyes. In institutions where sexual abuse and violence against children was rife (Hill, 2017; Humphreys, 2011), this isolation might have had even more sinister motivations.

\section{IDENTITY AND FAMILY}

Each of the four books demonstrates the life-long impacts of forced migration and an institutionalised childhood in an alien environment. Whilst the migrant programmes purported to foster and develop the young people as new Australians, the reality for many was an experience of displacement and lack-of-belonging. In a very tangible affront to identity, Margaret Humphreys (2011) explains that some child migrants were not provided with copies of their birth certificates and were therefore unable to prove their identity and apply for an Australian Passport. This lack of identity documentation simultaneously entrapped them in Australia, whilst denying them the rights of Australian citizens (see also, King, 2003). For other child migrants, the stigma and marginalisation associated with their migrant status reflected social rather than legal reaction to the children. David Hill (2017)

3 These deprivations are recounted in all four of the literary sources. 
discusses the way in which children from the Fairbridge Farm School were ostracised in the town high school in Orange, easily identified by their lingering English accents and shabby uniforms. However, the theory of narrative inheritance - that is, 'stories given to children by and about family inheritance' (Fitzpatrick, 2018, p. 44) - suggests that the crux of child migrants' crises of identity in fact lay not with this lack of citizenship, or the experience of stigma, but with the absence of family relationships. In other words, that it is difficult to create one's own identity without a solid understanding of the identity of your forbearers.

Although many child migrants like David Hill and Rosemary Hayes’ Kathleen, were institutionalised, these institutions were distributed across Australia. Other children sent to Australia, like Michael Morpurgo's Arthur, were sent alone or in small groups to foster families. Thus, none of the individual children, or small groups of children, understood the scale of the child migrant scheme, nor indeed realised that there was a scheme beyond the event that had happened to themselves and a small group of those they knew (Humphreys, 2011). Thus, not only were child migrants state-less and without family, they did not have a sense of belonging to a wider group of children who had this shared experience. Margaret Humphreys, in uncovering the scale of the process of twentieth-century child migration, was able to provide child migrants with a sense of belonging, if not to a nation, or to a specific family, to a group of people with shared experience. Indeed, reflecting on the work of Humphreys, one former child migrant, Harold Haig, explains: "What Margaret did for me and for thousands of child migrants is give us back our lives, give us back our identity...” (Barkham, 2011).

Rosemary Hayes (2001, p. 183) illustrates this sense of displacement in lyrics she writes to accompany her novel:

And will I ever see the faces of my youth? Will memories fade and blood ties severed be? Will distance mean that I shall be a refugee for life? My past wiped out and buried by the sea?

The innocents who left their native land And boarded ship to seek a better life How could they know, how could they understand The bitterness to come, the inner strife?

To make our way as children with no roots Or mother love To settle in a country harsh and bold To leave the past behind us, to forget our place of birth And keep the rules and never break the mould 
Hayes' lyrics here allude to two, interconnected, tragedies for these children. The first, that they were removed from a country whether they felt they belonged. The question of being a 'refugee for life' is certainly emotive, and does reflect this sense of not-belonging that is so clearly illustrated by the stories of former child migrants in Humphrey's work, who spent so long with no clear citizenship. Secondly, and certainly more traumatic from a contemporary perspective (Fink, 2007), the poem highlights the tragedy that they were removed from families, and broader social networks and supportive or caring relationships. The poem alludes to the fact that these children will grow up without familial ties or a relationship with parents "to make our way as children with no roots, or mother love", but also, and more sinisterly, suggests that there may have been relatives from whom the child migrants were forcibly separated: "will memories fade and blood ties severed be?”.

Whilst Arthur, Morpurgo's protagonist, undertakes migration as an orphan, many of the child migrants did indeed have living relatives, often parents, in the UK. In some cases children were supposed only to be in the temporary care of the state, at the time in which they were in fact sent to Australia. Humphreys (2011) recounts a harrowing story of a single mother who had placed her child temporarily in the care of a local children's home whilst she found work and suitable accommodation. She visited her son, and paid towards his upkeep. She soon remarried and with the blessing of her new husband returned to the home to reclaim her son, only to find that he had recently been sent to Australia. Despite many letters to various authorities and politicians, from both herself and her new husband, her son was not returned, nor was she able to secure any details about his whereabouts or condition. Heart-wrenchingly, Humphreys describes a common practice of informing migrant children that they were orphaned, in order to sever their ties with Britain. Meanwhile, parents in the UK were on occasions told that their children had died, in order to stop them searching (Humphreys, 2011).

For many child migrants, the institutions, their staff, and the other children became the only homes and families they were to know before adulthood, and their own attempts to forge homes and families for themselves. For many children, whilst coming of age and leaving institutions might have seemed like freedom finally won, the situation of immediate aloneness, may even have been worse. Humphreys describes girls such as Pamela Smedley sent as domestic workers to isolated households where they worked under harsh conditions and experienced extreme loneliness. For Kathleen, the child migrant in Rosemary Hayes' novel, simply leaving the institution was a huge wrench; as uncomfortable as it was, it was at least known. Going in to the world, with no social connections and no 
knowledge of life outside the institution, was terrifying for her. Humphreys (2011) and Hill (2017) both talk of many former child migrants who were simply unable to adjust to adult life without the stability of familial and social networks to support them. No after care was offered to help process the childhood trauma of being forcibly migrated. As such, both memoirs present former child migrants who turned to alcohol or drugs for support, or who suffered mental illness, some of whom ended up killing themselves. In Morpurgo's novel, the adult Arthur experiences the suicide of his close friend, also a former child migrant, and later he himself sinks into the clutches of addiction and deep depression. He eventually also attempts to kill himself and is ultimately rescued by the love of one of the nurses on his ward, who becomes his wife.

The story of redemption through relationships in adulthood comes out time and again in the tales of former child migrants. It is through positive interpersonal relationships as adults that many former child migrants were able to come to terms with the trauma and abuse experienced in their childhood and move forward in creating their own lives. Thus some former child migrants were only able to forge an identity as new Australians when they found themselves able to share their history with someone who cared about them. Both Arthur and Kathleen manage to sustain happy marriages. Kathleen shuts away the painful memories of the past, and shares them only posthumously with her grand-daughter in her grand-daughter's dreams. In a real-world parallel, the academic Margaret McNay discusses in a methods paper on 'narrative inheritance', her own experience of discovering her father's history as a Canadian child migrant, only after his death (McNay, 2009). McNay's father had, as Kathleen, colluded with a spouse to keep the history he viewed as shameful, from his daughter. Morpurgo's Arthur, whose life is transformed through marrying into a large but close-knit Greek-Australian family is, by contrast, able to share his past directly with his teenage daughter, as she scribes his memoirs for him. The lives recounted by Humphreys and Hill both gravitate towards variations of the latter, as of course it is only through self-identification as a child migrant that people contributed to their publications.

At the risk of implying that forging a new identity and creating a positive life story rested solely in the hands of former child migrants, it is important to draw out the role that public recognition of child migrant status, and both state and agency apologies, might have played in redefining these adults' lives. Whilst the last child migration scheme ended in 1967, it is only in the last decade that the British and Australian governments have officially apologised for the role they played in this atrocity. Prime Minister Gordon Brown's apology on behalf of the British Government in 2010 was accompanied with the promise of a Ł6m Family 
Restoration Fund to help former child migrants reunite with relatives in the UK (Bowcott, 2010). However, this reparation was viewed as far from sufficient by the UK’s Independent Inquiry into Child Sexual Abuse (IICSA) (Bowcott, 2018). The first written report of the Inquiry that opened in 2015 focuses on the British child migrant scheme and recommends compensation payments to all child migrants in recognition of their risk of exposure to sexual abuse (IICSA, 2018). Moreover, the report recommends public and personal apologies from all institutions involved in the schemes, in recognition of the reticence of many of the organisations to do this up to this point.

The very fact of the IICSA public inquiry addressing child migration, following the Parliament of Australia's much earlier Inquiry into child migration in 2001, might be seen to have changed the public narrative of child migration in Australian and in Britain (Swain, 2016). According to Swain (2016, p. 148), involvement in public inquiries allowed child migrants to be "co-authors of their own histories, and key players in the national story”. Indeed, Swain identifies funding for national history projects to be a key element of the Australian reparation packages offered as a result of inquiries into the experience of Australian Care Leavers, involving particularly stolen Aboriginal children and British child migrants. Public recognition, fought hard for by Margaret Humphreys and activist child migrants such as David Hill, may legitimize the experience of former child migrants, vindicating them of any notion that they themselves might have deserved this childhood experience, or that it might have been 'for the best'. Co-authoring the history of child migrants into a shared inheritance narrative, or collectively produced identity, allows for the re-emergence of the story of this diasporic group into an ongoing narrative that might be inherited by generations to come.

\section{CONCLUSION}

The story of the scandal of British child migrants moved against their will from Britain to the colonies might be interpreted as a story of a crime against identity. Through the process of forced migration, children's ties were cut both with the landscapes with which they were familiar, and with social networks. These social networks might have been the friends and carers with whom they were familiar, but in many tragic cases, this included parents or other close relatives. The dual severance was itself an outcome of the children's former identities, as working class, and therefore deemed of little value in Britain, whilst see as valuable for their whiteness in a colonial context. Promised an identity as new Australians, 
these children were largely institutionalised, segregated from local communities of Australians, and grew up with no clear sense of identity as either Australian or British. The education and training undertaken within institutions did not prepare these children for integration into Australian society, and many child migrants left institutions as adults devoid of appropriate training and qualifications, and with no social networks on which to rely. Through developing personal relationships, and finally, through a public unveiling of the child migrant scandal, some child migrants were able to gain a sense of identity at the intersection of British, Australian, victim and agentic member of the communities of loved ones they had forged. However, the centuries of child migration, and the decades of delay following the end of the post-war child migrant schemes, meant that collective action and public apology came too late for most.

\section{Acknowledgements}

This research is funded by a Royal Geographical Society Small Grant (SRG 09/18).

I would like to thank the members of Lancaster Environment Centre's Critical Geographies Research Group, and attendees at the International Migration and Mobilities Conferences 2018, for their helpful reflection and contribution to the development of this paper.

\section{Key Texts}

Hayes, R. (2001). Blood Ties. Victoria: Penguin Books Australia Ltd.

Hill, D. (2017)4. The Forgotten Children: Fairbridge Farm School and Its Betrayal of Britain's Child Migrants. London: Allen and Unwin.

Humphreys, M. (2011)5. Empty Cradles. London: Transworld Publishers.

Morpurgo, M. (2007). Alone on a Wide Wide Sea. Holmfirth, UK: HarperCollins Children's Books.

\section{Additional References}

Barkham, P. (2011). Child Migrants: 'I Didn’t Belong to Anybody’. The Guardian [26.07.2018]. Retrieved from: https://www.theguardian.com/society/2011/apr/07/child-migrantsoranges-and-sunshine-film.

BBC News Magazine (2015). The 13-Year-Old Girl Sent on a 'Day-Trip' to Australia [online]. Retrieved from: https://www.bbc.co.uk/news/magazine-34656346 (accessed: 27.07.2018).

4 First published in Australia in 2007 by Random House Australia.

5 First published in Great Britain in 1994 by Doubleday. 
Bean, P., \& Melville, J. (1989). Lost Children of the Empire. London, UK: Unwin Hyman Ltd. Beyer, C. (2010). Exploring Postcolonial and Feminist Issues: 'Rabbit-Proof Fence' in a Teaching Context. Changing English: Studies in Culture and Education, 17(1), pp. 93-101. DOI: 10.1080/13586840903557100.

Bowcott, O. (2010). Brown Apologises for Britain's 'Shameful' Child Migrant Policy. The Guardian [online]. Retrieved from: https://www.theguardian.com/society/2010/feb/24/ british-children-sent-overseas-policy (accessed: 27.07.2018).

Bowcott, O. (2018). Inquiry Urges Payouts for Victims of Postwar UK Child Migration Scheme. The Guardian [online]. Retrieved from: https://www.theguardian.com/society/2018/mar/01/inquiry-urges-payouts-for-victims-of-postwar-uk-child-migrationscheme (accessed: 29.07.2018).

Coldrey, B. (1996). 'A Charity Which Has Outlived Its Usefulness': The Last Phase of Catholic Child Migration, 1947-56. History of Education, 25(4), pp. 373-386. DOI: 10.1080/004 6760960250406.

Constantine, S. (2002). The British Government, Child Welfare, and Child Migration to Australia after 1945. The Journal of Imperial and Commonwealth History, 30(1), pp. 99-132. DOI: 10.1080/03086530208583135.

Dunae, P. (1988). Waifs: The Fairbridge Society in British Columbia, 1931-1951. Histoire Sociale/Social History, 21(42), pp. 224-250.

Fink, J. (2007). Children of Empire: The alignments of church, state and family in the creation of mobile children. Cultural Studies, 21(6), pp. 847-865. DOI: 10.1080/0950238070147 0650 .

Fitzpatrick, E. (2018). A Story of Becoming: Entanglement, Settler Ghosts, and Postcolonial Counterstories. Cultural Studies - Critical Methodologies, 18(1), pp. 43-51. DOI: 10.117 $7 / 1532708617728954$.

Grant, E., \& Sendziuk, P. (2010). ‘Urban Degeneration and Rural Revitalization': The South Australian Government’s Youth Migration Scheme, 1913-14. Australian Historical Studies, 41(1), pp. 75-89. DOI: 10.1080/10314610903483523.

Grier, J. (2002). Voluntary Rights and Statutory Wrongs: The Case of Child Migration, 194867. History of Education, 31(3), pp. 263-280. DOI: 10.1080/00467600210122621.

Henrich, E. (2014). Children's Toys and Memories of Migration in Australian Museums. Childhood in the Past, 7(2), pp. 133-146. DOI: 10.1179/1758571614Z.00000000022.

IICSA (2018). Interim Report of the Independent Inquiry into Child Sexual Abuse [online]. Retrieved from: https://www.iicsa.org.uk/interim-report (accessed: 27.07.2018).

Kershaw, R., \& Sacks, J. (2008). New Lives for Old: The story of Britain's Child Migrants. Kew, Richmond, Surrey, UK: The National Archives.

King, D. (2003). Gender Migration: A Sociological Analysis (or The Leaving of Liverpool). Sexualities, 6(2), pp. 173-194. DOI: 10.1177/1363460703006002002.

Langfield, M. (2004). Voluntarism, Salvation, and Rescue: British Juvenile Migration to Australia and Canada, 1890-1939. The Journal of Imperial and Commonwealth History, 32(2), pp. 86-114. DOI: 10.1080/0308630410001700417.

McNay, M. (2009). Absent Memory, Family Secrets, Narrative Inheritance. Qualitative Inquiry, 15(7), pp. 1178-1188. DOI: 10.1177/1077800409334236. 
OTO (undated). On Their Own: Britain's Child Migrants. Pamela Smedley: Longing for a Family [online]. Retrieved from: http://otoweb.cloudapp.net/new-lands-new-lives/schemes/ pamela-smedley.html (accessed: 27.07.2018).

Sherington, G. (2003). 'Suffer Little Children': British Child Migration as a Study of Journeyings between Centre and Periphery. History of Education, 32(5), pp. 461-476. DOI: 10.1080/0046760032000118282.

Silverstein, J. (2017). 'The Beneficent and Legal Godfather’: A History of the Guardianship of Unaccompanied Immigrant and Refugee Children in Australia, 1946-1975. The History of the Family, 22(4), pp. 446-465. DOI: 10.1080/1081602X.2016.1265572.

Stack, J. (1979). The Provision of Reformatory Schools, the Landed Class, and the Myth of the Superiority of Rural Life in Mid-Victorian England. History of Education, 8(1), pp. 33-43. DOI: 10.1080/0046760790080103.

Swain, S. (2016). Beyond Child Migration: Inquiries, Apologies and the Implications for the Writing of a Transnational Child Welfare History. History Australia, 13(1), pp. 139-152. DOI: 10.1080/14490854.2016.1156212.

The Telegraph (2015). In Pictures: The Belongings of Britain's Child Migrants [online]. Retrieved from: https://www.telegraph.co.uk/art/what-to-see/gallery-britain-childmigrants-v-a-exhibition/pamela-mary/ (accessed: 27.07.2018).

Uusihakala, K. (2015). Rescuing Children, Reforming the Empire: British Child Migration to Colonial Southern Rhodesia. Identities: Global Studies in Culture and Power, 22(3), pp. 273-287. DOI: 10.1080/1070289X.2014.939184. 